\title{
Global industry perspective of halal cosmetics applying sales and distribution process based on enterprise resources planning
}

\author{
Khairen Niza Mefid ${ }^{1, *}$, Ari Yanuar Ridwan ${ }^{2}$, Warih Puspita Sari ${ }^{3}$ \\ Faculty of Industrial Engineering, Telkom University, Bandung, Indonesia \\ ${ }^{1}$ khairennizam@gmail.com *; ${ }^{2}$ ari.yanuar.ridwan@gmail.com; ${ }^{3}$ warihpuspita@gmail.com \\ * corresponding author
}

\begin{tabular}{|c|c|}
\hline ARTICLE INFO & ABSTRACT \\
\hline $\begin{array}{l}\text { Article history } \\
\text { Received September 2, } 2019 \\
\text { Revised September 29, } 2019 \\
\text { Accepted October 10, } 2019 \\
\text { Keywords } \\
\text { Global industry } \\
\text { Halal cosmetics } \\
\text { Sales and distribution process }\end{array}$ & $\begin{array}{l}\text { The cosmetics industry has several business processes from procurement to } \\
\text { sales and distribution of products; thus, it requires a system that can integrate } \\
\text { and monitor business processes under halal standardization. This paper } \\
\text { discusses the use of ERP systems in the application of Odoo } 10 \text {.0 Halal sales and } \\
\text { distribution modules using the ASAP (Accelerated SAP) method. Halal system } \\
\text { integration allows users to find out the sales results in real-time and can do } \\
\text { documentation in the form of customer data, quotations, sales orders, invoices, } \\
\text { delivery orders. In addition, the main element is the halal report on sales } \\
\text { management that can store and show reports for the marketing department. } \\
\text { This halal ERP system can be adapted to the needs of companies to face global } \\
\text { challenges. }\end{array}$ \\
\hline
\end{tabular}

This is an open access article under the CC-BY-SA license.

\section{Introduction}

The cosmetics industry is a contract manufacturing industry engaged in beauty. This industry carries out the process of product development, manufacturing, packaging, sales and distribution for skincare, as well as for the professional skincare label industry. However, only a small number of cosmetic companies have halal certification. Cosmetics that are not halal mean in the manufacturing process using illicit substances according to Islamic religious rules. Non-halal cosmetics means that during the manufacturing process, the factory used non-permissible substances according to Islamic rules.

The cosmetics industry needs a system that integrates its business processes and monitor processes following halal standardization. An integrated system should be able to manage, monitor and minimize errors in the company. The integration of information systems or appropriate technology can support the company's business plans and development, which will later provide added value in the form of comparative disadvantage in business competition [1], [2].

One information technology that is available to support the business process is Enterprise Resource Planning (ERP). ERP is the core software used by companies to integrate every business process in order to support the management reporting process [3]. One ERP application that is often used is Open ERP (Odoo). This business application has complete modules from sales, CRM, project management, warehouse management, manufacturing, financial management, and human resources, as well as many supporting modules. Odoo has several characteristics, such as customizable, comprehensive, modular, and open-source [4]. One of the modules, the sales module, allows users to manage and classify sales orders in a structural and hierarchical system. Users are allowed to make new orders and review existing orders in various countries. Order confirmation can automatically set the delivery schedule for goods, invoices and time determined by the settings in each order. In this module, the 
seller acquired all the information needed in just one screen and can control the ordering and shipping of goods. The sales management module is very close to the manufacturing and warehouse modules.

This paper aims to discuss the inclusion of halal reports on business processes, mainly cosmetics industry sales and distribution. This model employed ASAP, a methodology recommended by SAP for other companies if they intend to implement ERP system applications [5]. The ASAP methodology is a methodology that has a structured roadmap that is accessible to determine strategy. The phases included are project preparation, blueprint, realization, final preparation and go-live support [6]. Also, it discusses the views of the international community regarding the halal industry which primarily implements ERP.

\section{Global Perspective of Halal Cosmetics Industry}

The total of the global Islamic population is massive, and it is still increasing. There are in excess of 2 million Muslims who are spread more than 112 nations, crosswise over different areas such as the Organization of Islamic Cooperation (OIC) nation (1.4 billion), Asia (805 million), Africa (300 million), the Middle East (210 million), Europe (18 million), and North America (8 million) [7]. With Muslims currently making up one-fourth of the total global population, the markets' development is tremendous. One of the main issues for Muslim consumers is the need for halal products. The Halal industry covers food, non-food products such as pharmaceuticals and cosmetics, and services, including logistics, tourism, and marketing.

Especially in the cosmetics industry, market development is reflected by a customer insight about the ingredients used and product awareness. The fundamental driver for this massive need in halal cosmetics and beauty care products comes from the statistic of teenagers, religiously cognizant, and dynamic expert Muslim population. In the extent of halal cosmetics, the idea covers essential parts of production, for example, permissible ingredients and use of permissible substances which must be made, stored, packaged, and delivered following Shari requirements [8]. The market for halal beauty care products is blasting in the Middle East and Asia. Over the Middle East, halal beauty care products are enlisting a $12 \%$ yearly development coming to USD12 billion in total value of cosmetic related sales. Markets in Asia, especially Malaysia and Indonesia, just as Europe, have seen a flood in enthusiasm for halal cosmetics [9].

The cosmetics business needs to understand customer concerns, awareness, expectations, use of halal cosmetics. It will assist them in earning more profit. Halal cosmetics are convenient for both Muslims and non-Muslim in terms of ingredients, procedure, and nature of the items. In this way, association and brands of cosmetics need to create specialty market of halal cosmetics to do design up to some expand adequately in Muslim religiosity [10].

The worldwide halal cosmetics market will prosper that meets the religious necessities of Muslims. Expanded degree of education and awareness, expanded the need to build up, and create general gauges for Halal items including cosmetics. It is significant for the cosmetics industry to satisfy customers' needs and make the benefit alongside satisfying the social obligations to fulfill cognizant wellbeing customers. Research on Halal products expanded awareness to support manufacturers, producers, and marketers ought not just to consider how to increase the profit, yet in addition, they have to know initial preparation about halal to urge them to makes really halal products. Researchers argue that buyers tend to choice halal product and they are pleased to pay more for halal-labeled brands [11].

\section{Business Process of Halal Cosmetic Industry}

The business process of the halal cosmetic industry consists of various features. There are nine features, which will be detailed in the next sections.

\subsection{Halal Customer}

Cosmetics factories need a system that is capable of storing Halal customer data. Commonly, the customer data collection process only uses forms. Development of a sales management module, allows customer information or data to be stored and configured on the Customer features.

Fig. 1 shows the customer form contained in the Odoo application. There are some data needed such as an address for the customer's address and product delivery, phone number, email to send 
quotations to customers, and language options. In addition, it shows in the figure that there is a custom field, the Demands for Halal Products field. The field is used to determine the demand for halal products needed by the customer.

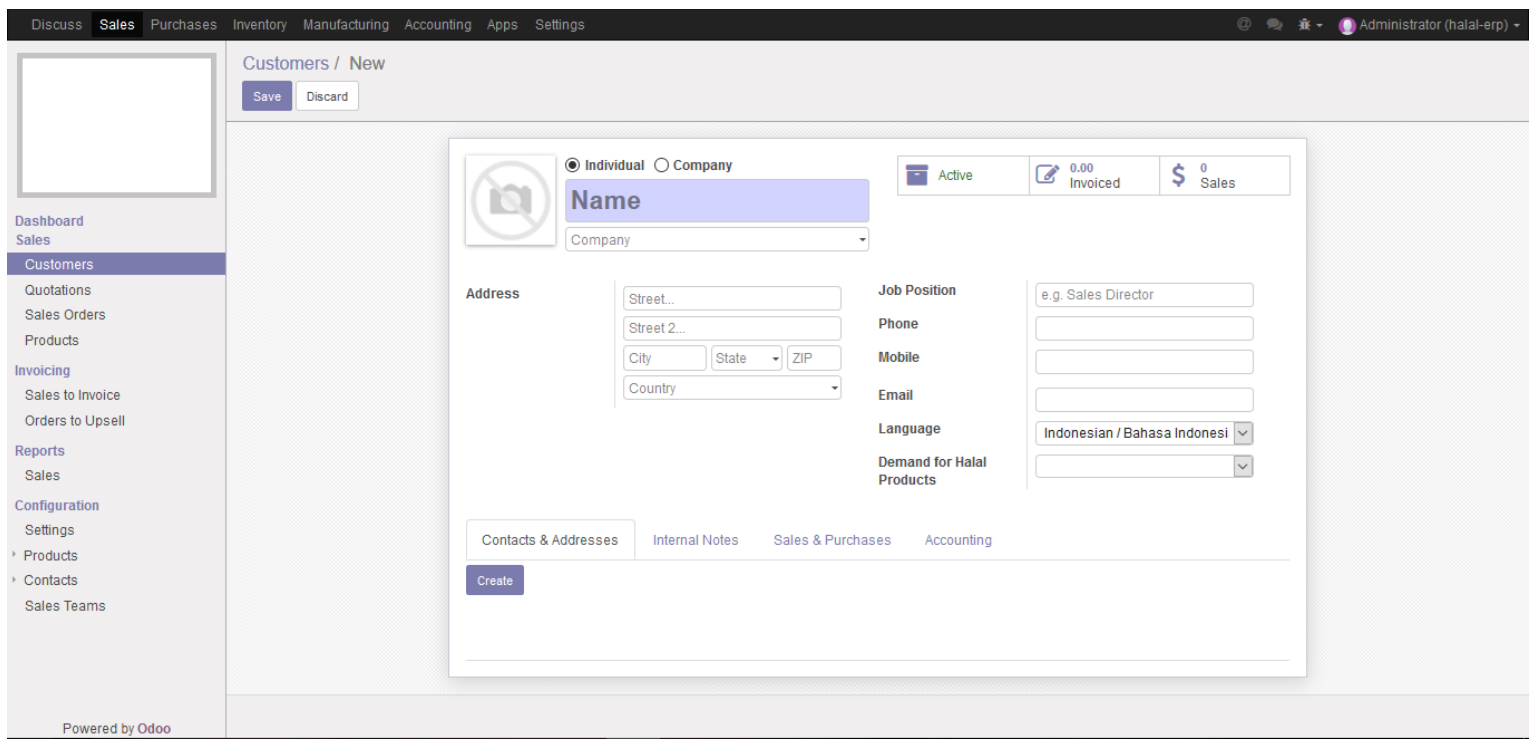

Fig. 1.Halal customer

\subsection{Halal Quotation}

Cosmetics factories need a form to offer Halal products sent to customers. After being confirmed by the customer, it will become a Sales Order. In the application, the bidding process is still done manually and orally between the marketing and customer sections. In the future, the product offering process (quotation) conducted on sales management can be stored in a database. Quotations can be sent directly to customers through send by email feature. After the confirmation from the customer, it can be generated into a Sales Order (data ordering goods). Also, it allows customizing the halal fields needed in product offerings.

Fig. 2 shows the quotation form (product offer form). The form contains information about customer data, invoice address, delivery address, order date, expiration date, and payment terms. There is a custom field in Fig. 2, namely the demands of the field for halal products and a total of halal-certified products. The customization is carried out to determine the demand for halal products and the total of products that have halal certification in the company. The quotation can be sent directly to the customer by clicking the send by email button.

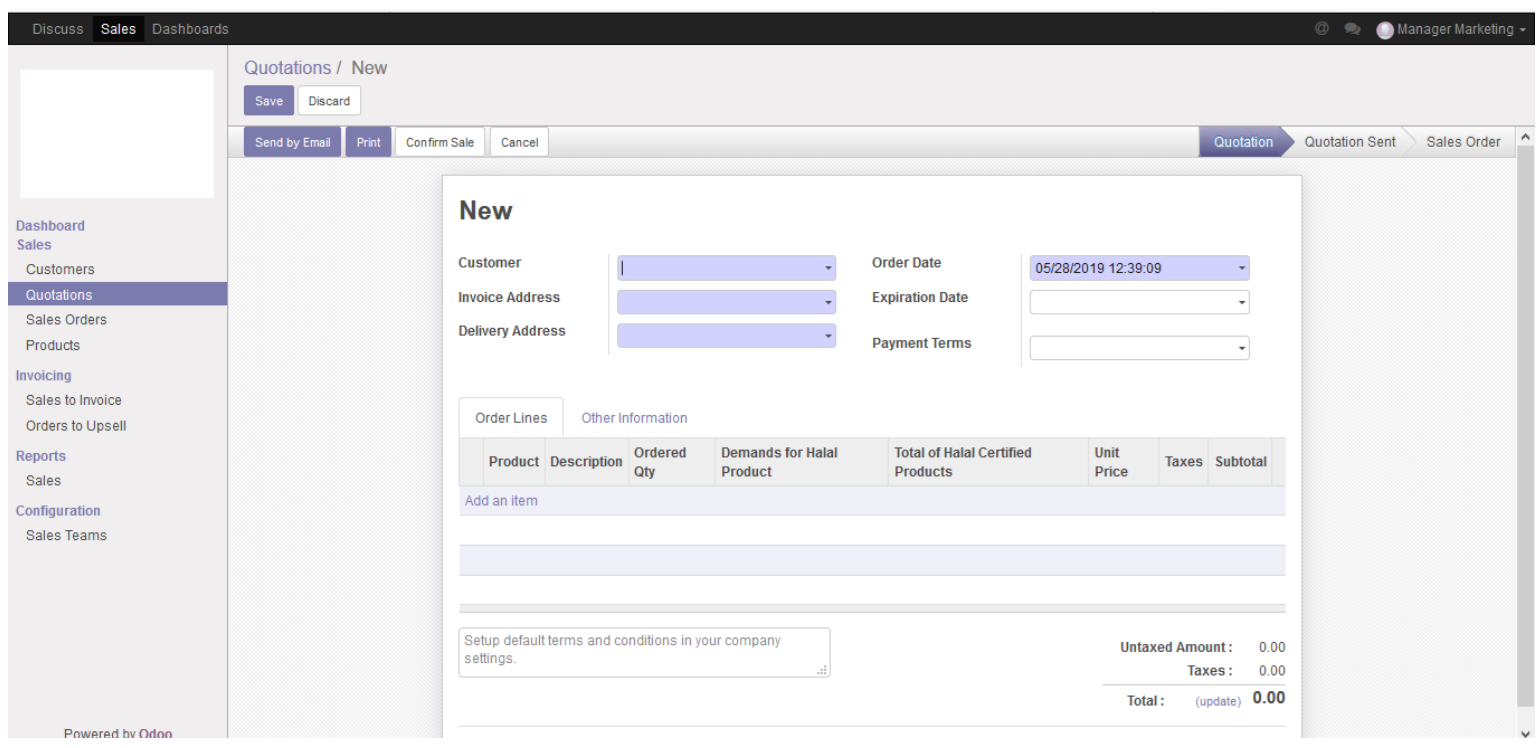

Fig. 2.Halal Quotation 


\subsection{Halal Sales Order}

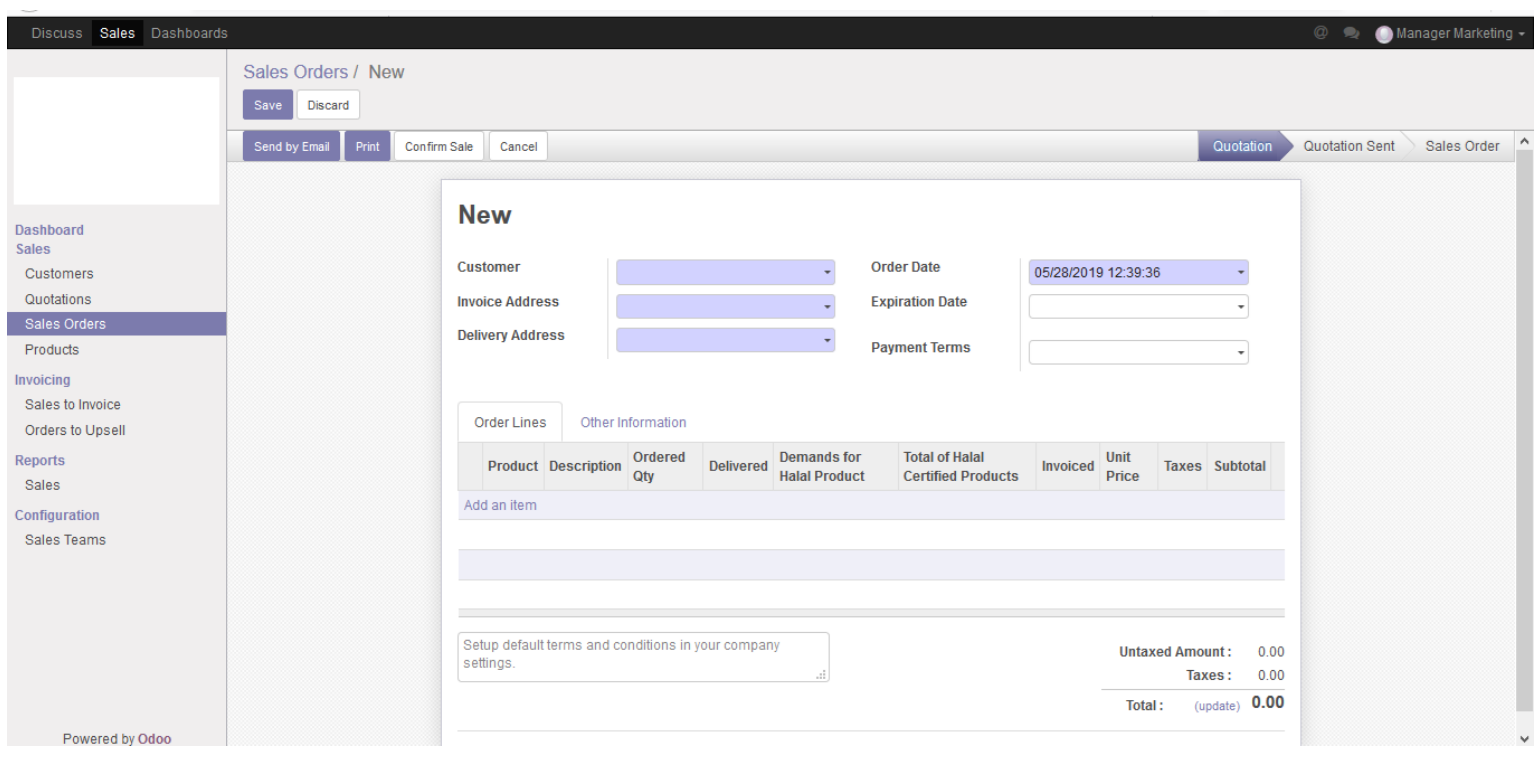

Fig. 3. Halal sales order

Ideally, users need a system that can send Halal Sales Order documents directly with integrated information. However, usually, Sales Orders are sent to the production department in the form of documents that are created manually. In the upcoming future, with the integration of Sales Management and Manufacturing, the sales order will automatically become a manufacturing order.

Fig. 3 shows the sales order form. The sales order form is generated from the quotation form after it has been sent to the customer and received confirmation from the customer; the manager can click the confirm sale button.

\subsection{Halal Shipping}

In the shipping process, there needs to be a system that regulates the process of moving halal products to customers. Recently, no system regulates the process of moving the finished product to the customer. In the upcoming future, when the manufacturing department has produced the goods, then the product will be picked up for packing and transferring in the form of a delivery order to the customer according to the sales order. Odoo can do customization to check products according to halal standardization.

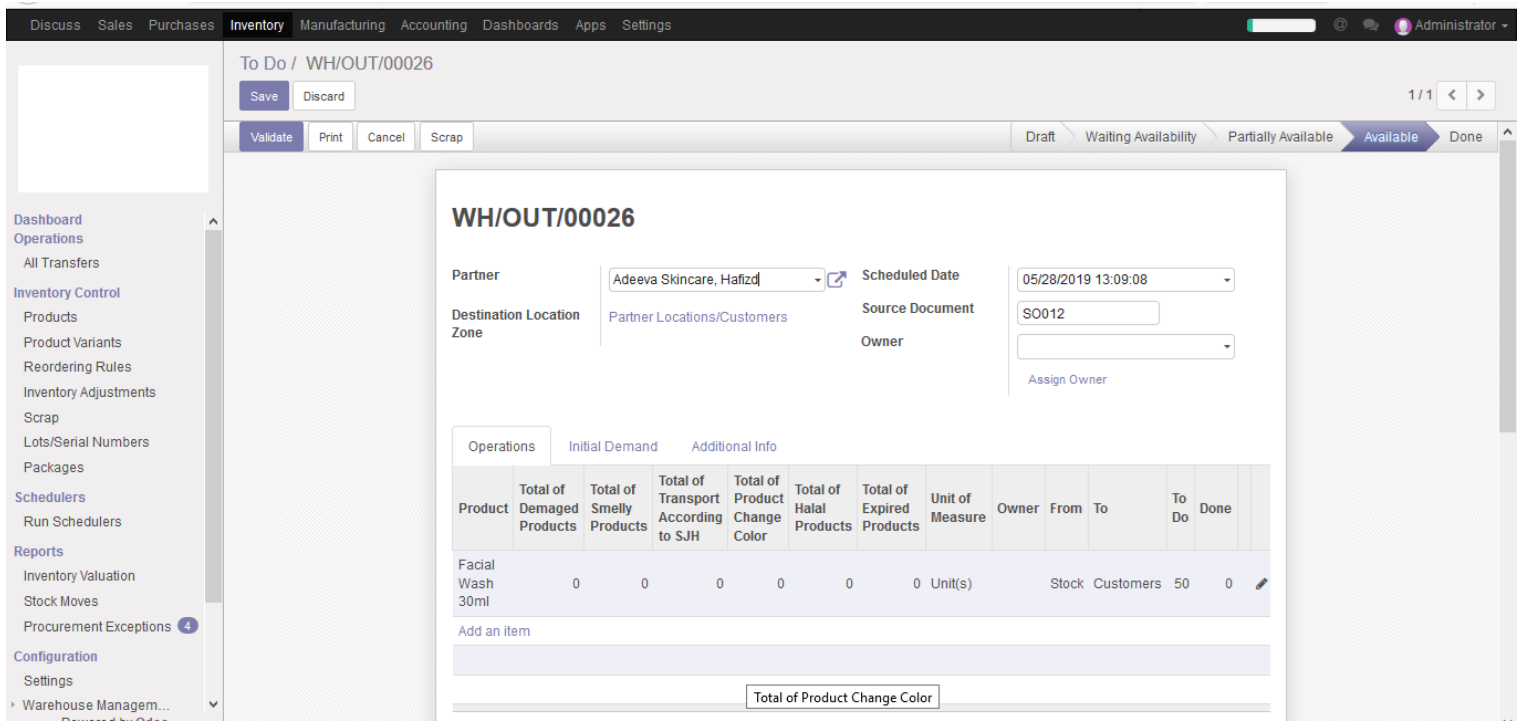

Fig. 4.Halal Shipping 
In Fig. 4, a delivery order form is a form that contains partner data (product ordering) and products that will be sent to the customer. On the delivery order form, there is a customization of halal product specifications that are used to determine whether or not a product complies with halal provisions.

\subsection{Halal Return}

In the return process, the system requires checking the compatibility between the order data and the halal product sent. In the current system conditions, there is no system that regulates the process of returning goods from customers to companies. When goods that have been produced will be sent to the customer, there is a system that is able to document defect products thus the products that arrive at the customer are halal products.

In Fig. 5, it shows the order delivery form. There are customizations of the Halal Product Specifications Tab with the fields of the total of smelly products, total of damaged products, total of transport according to $\mathrm{SJH}$, total of product change color and total of halal products. These fields allow users to identify the total defect product. To do the return, users can click the cancel button. Thus, the customers will receive the halal product.

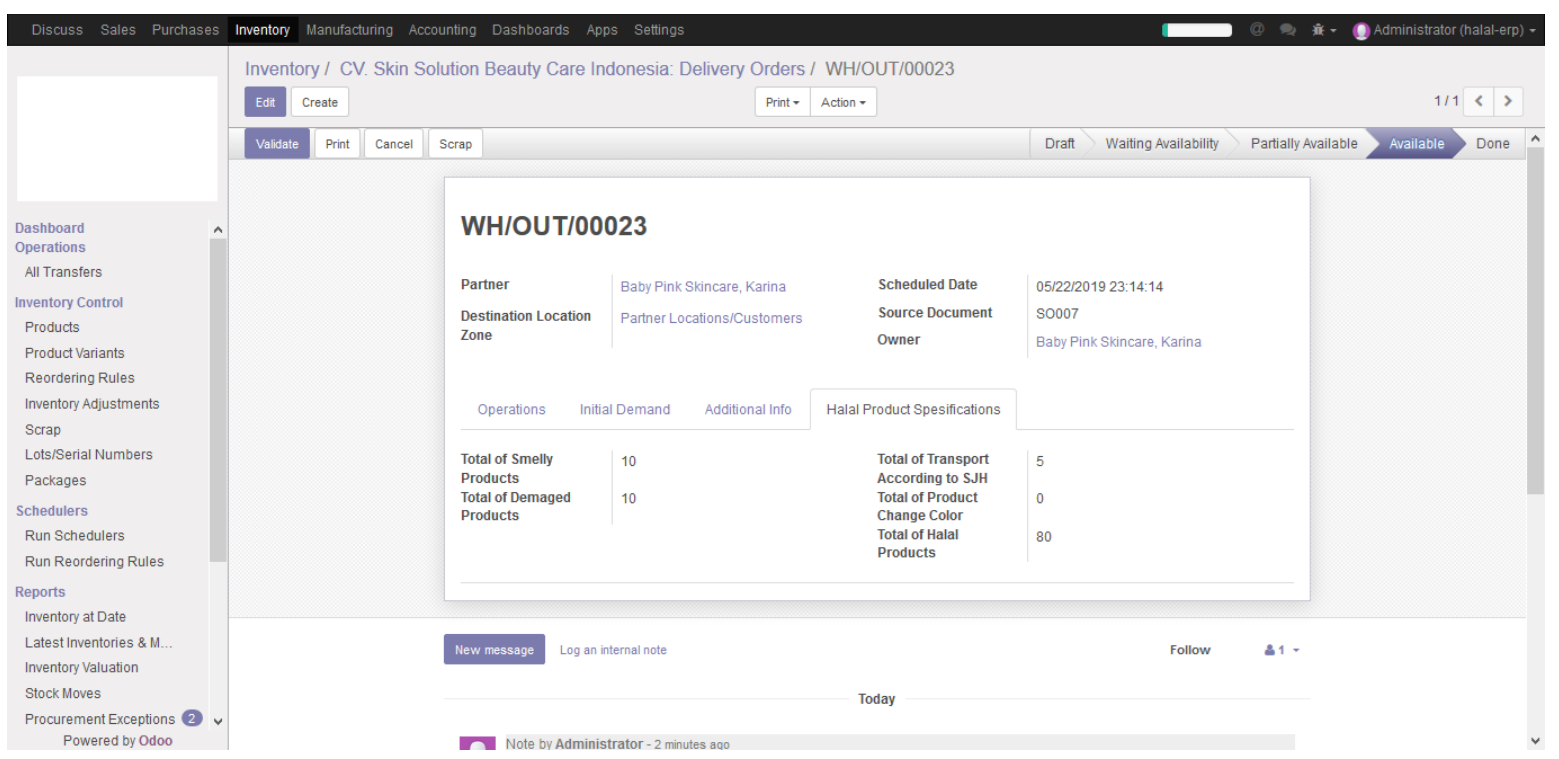

Fig. 5.Halal Return

\subsection{The Invoice Process}

It requires a system to create invoices based on customer orders and find out the payment status. However, billing payments are still manually done by employing Microsoft Excel (spreadsheet program). Ideally, the system can create a sales invoice that is integrated with the payment register. In Fig. 6, it addresses the invoice, which is generated from the sales order. The system can create sales invoices that are integrated with the payment register. 


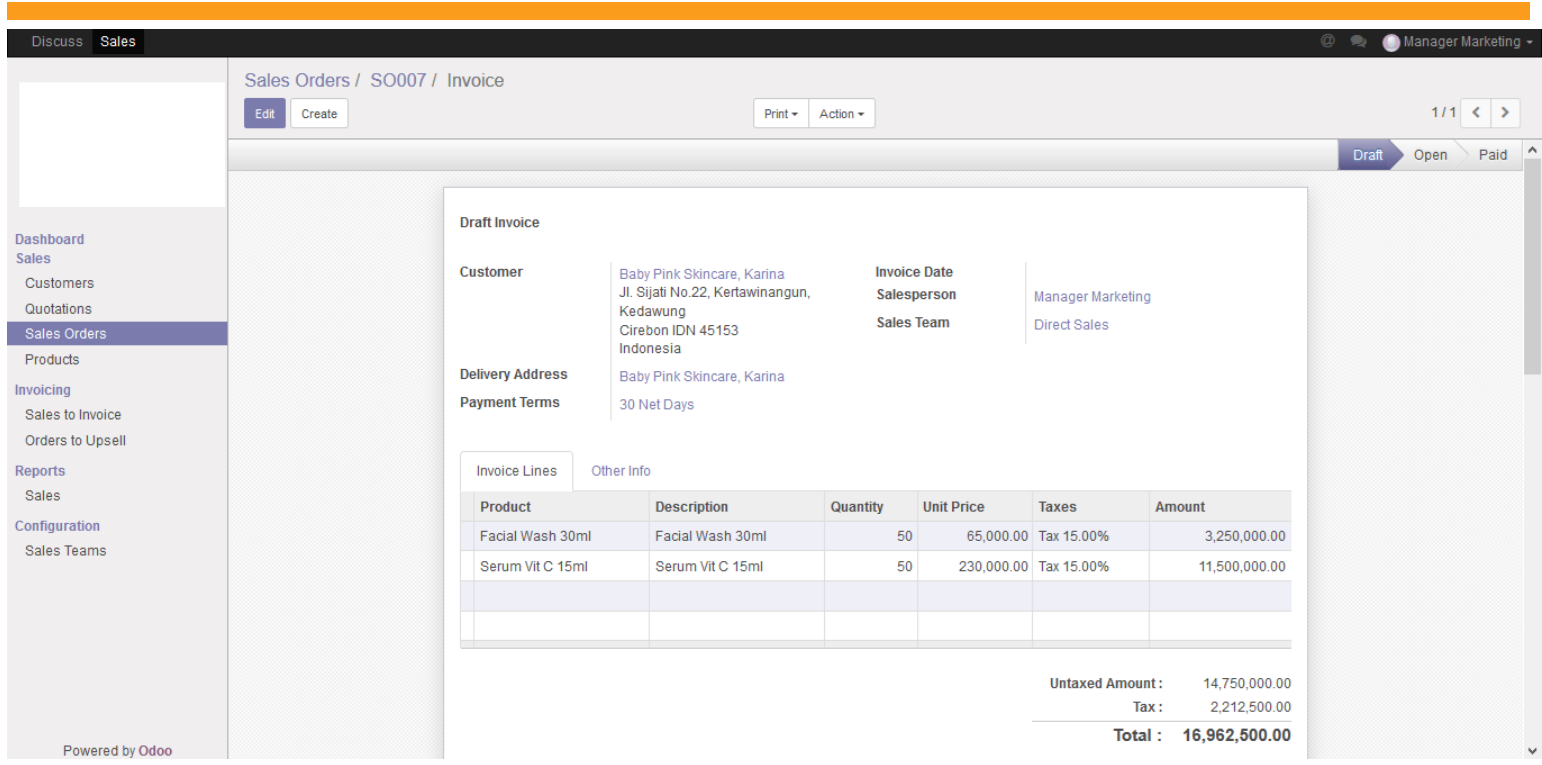

Fig. 6.Invoice process

\subsection{Report Quotation}

It requires a system design that can display reports on customer orders within a period (months). However, no system regulates the product ordering report process. Ideally, the system can create a customer order report that is in the sales management module in the quotation section by customizing it.

Fig. 7 presents the results of the report quotation that occurred in May. The report contains the total product offerings and a total of halal-certified products.

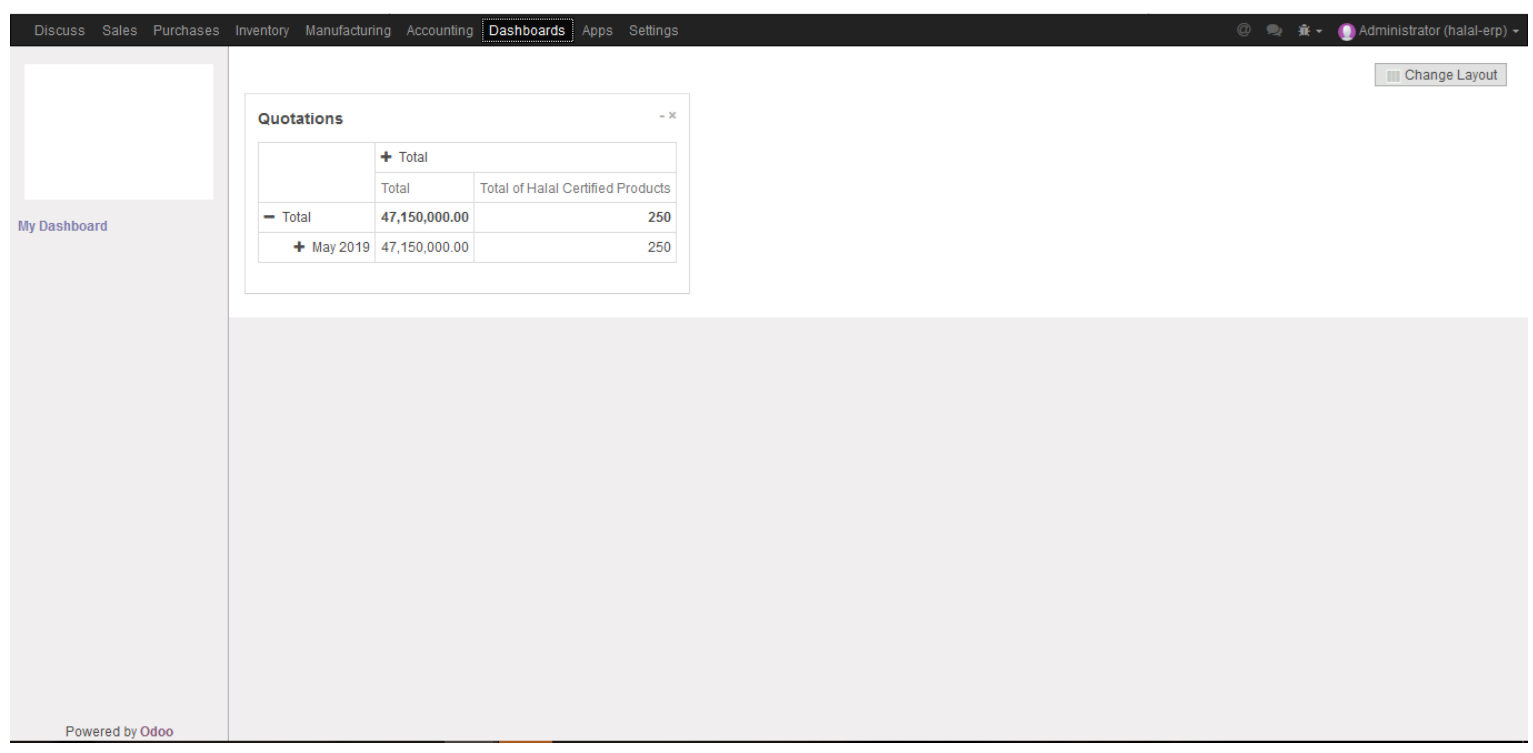

Fig. 7.Report Quotation

\subsection{Halal Sales Orders Report}

It requires a system design that can display reports on customer percentage orders within a period (months). However, no system regulates the product sales report process. Ideally, the system can create a customer order report that is in the sales management module in the quotation section by customizing it. Fig. 8 shows the results of a sales order report that occurred in May. The report contains total product sales and a total of halal-certified products. 


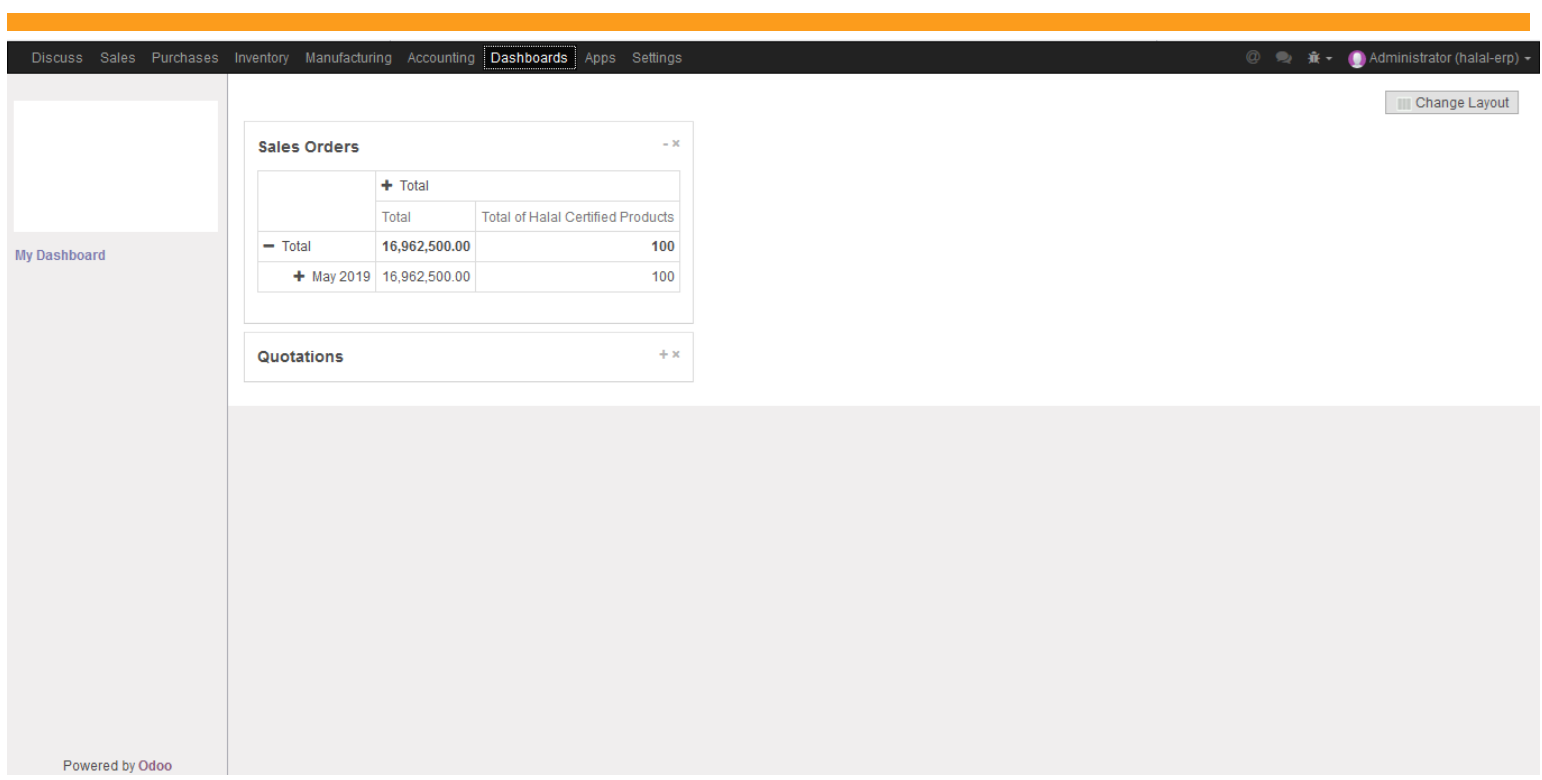

Fig. 8.Sales order report

\subsection{Halal Picking Operation Report}

Users need a system that can display reports for the process of product picking or picking operation. However, no system regulates the report picking operation process. Ideally, the system can create custom order reports, namely in the inventory management module, in the delivery order section by customizing.

In Fig. 9, it shows the results of the report picking operation. The report contains the products ordered, the number, the total of the product defects. This reporting is needed for company documentation.

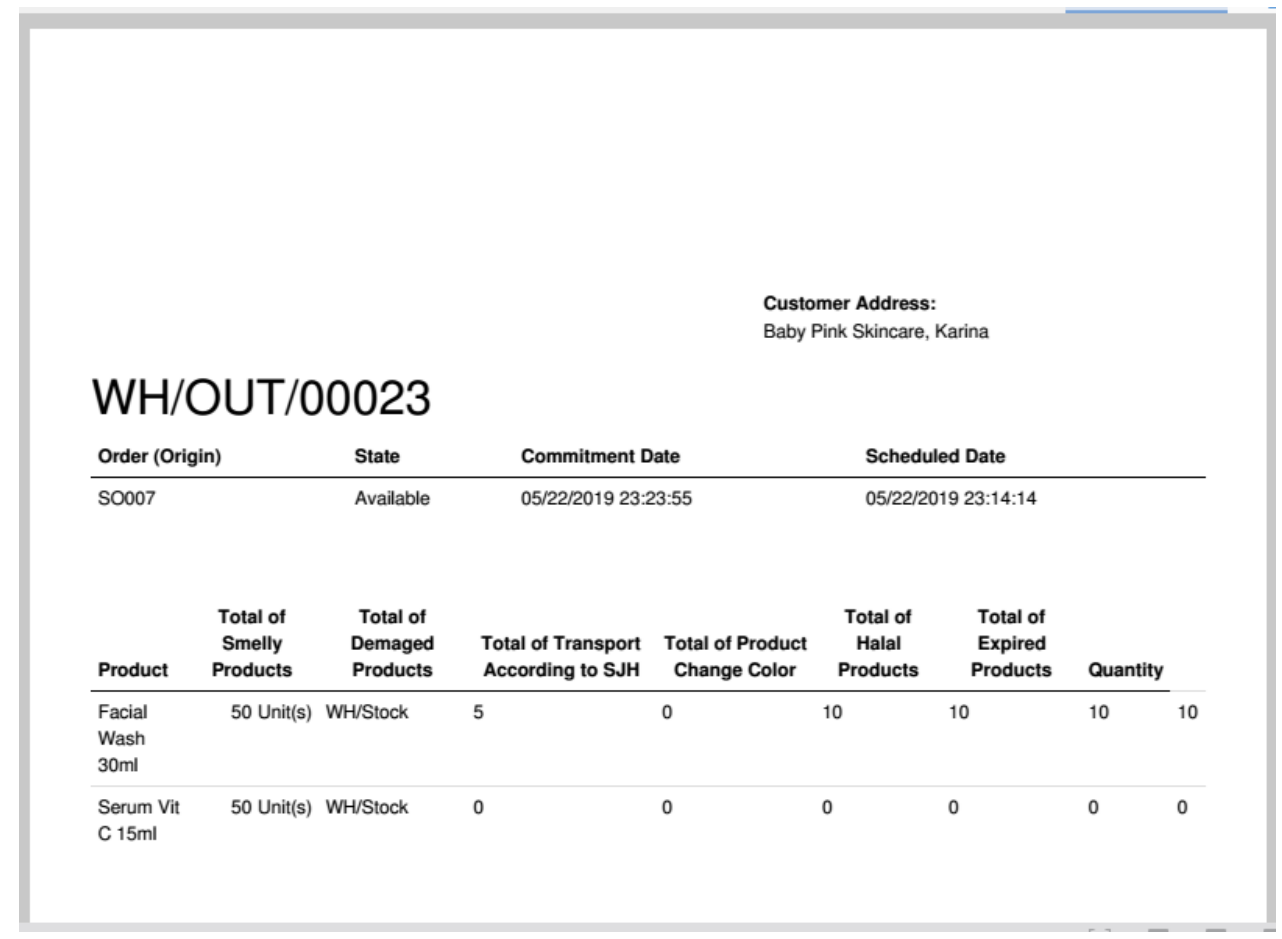

Fig. 9.Picking operation report 


\section{Conclusion}

Halal system integration allows users to find out sales results in real-time and can do documentation in the form of customer data, quotations, sales orders, invoices, delivery orders, and generates halal reports on sales management that are capable of saving and showing reports for the marketing department. This halal system design can be adjusted to the needs of the company in order to overcome the problems faced by the industry.

\section{References}

[1] A. Tarhini, H. Ammar, T. Tarhini, and R. E. Masa'deh, "Analysis of the critical success factors for enterprise resource planning implementation from stakeholders' perspective: A systematic review," Int. Bus. Res., vol. 8, no. 4, pp. 25-40, 2015.

[2] C. J. Costa, E. Ferreira, F. Bento, and M. Aparicio, "Enterprise resource planning adoption and satisfaction determinants," Comput. Human Behav., vol. 63, pp. 659-671, 2016.

[3] Y. Y1lmaz and G. Ozcan, "Implementing ERP-systems with accelerated ERP more efficient and quicklya best practice," J. Syst. Integr., vol. 2, no. 3, pp. 28-37, 2011.

[4] A. Ganesh, K. N. Shanil, C. Sunitha, and A. M. Midhundas, "OpenERP/Odoo-an open source concept to ERP Solution," in 2016 IEEE 6th International Conference on Advanced Computing (IACC), 2016, pp. $112-116$.

[5] F. Tasevska, T. Damij, and N. Damij, "Project planning practices based on enterprise resource planning systems in small and medium enterprises-A case study from the Republic of Macedonia," Int. J. Proj. Manag., vol. 32, no. 3, pp. 529-539, 2014.

[6] M. Wang, "Integrating ERP/SAP to Information Systems 2010 Curriculum: Design and Delivery," Inf. Syst. Educ. J., vol. 9, no. 5, p. 97, 2011.

[7] I. A. Latif, Z. Mohamed, J. Sharifuddin, A. M. Abdullah, and M. M. Ismail, "A comparative analysis of global halal certification requirements," J. Food Prod. Mark., vol. 20, no. sup1, pp. 85-101, 2014.

[8] M. A. Hassali, S. K. Al-Tamimi, O. T. Dawood, A. K. Verma, and F. Saleem, "Malaysian cosmetic market: Current and future prospects," Pharm. Reg Aff., vol. 4, no. 4, pp. 155-157, 2015.

[9] H. Elasrag, "Halal industry: Key challenges and opportunities," Munich Pers. RePEc Arch., no. 69631, 2016.

[10] M. B. Majid, I. Sabir, and T. Ashraf, "Consumer purchase intention towards Halal cosmetics \& personal care products in Pakistan," Glob. J. Res. Bus. Manag., vol. 1, no. 1, 2015.

[11]S. Ali, F. Halim, and N. Ahmad, "Beauty Premium and Halal Cosmetics Industry," J. Mark. Manag. Consum. Behav., vol. 1, no. 4, 2016. 